\title{
Pengembangan Inventori Prokrastinasi Akademik Bagi Mahasiswa
}

\author{
Umi Lailatussyifa' Farida Faradila ${ }^{{ }^{\star}}$, Blasius Boli Lasan ${ }^{2}$, Devi Permatasari ${ }^{1}$ \\ 1 Universitas Kanjuruhan Malang, Indonesia. \\ ${ }^{2}$ Universitas Negeri Malang, Indonesia. \\ *Korespondensi: umilailatussyifa@gmail.com
}

\begin{abstract}
This development research aims to produce an academic procrastination scale to measure the level of delay rate to complete tasks that have high validity and reliability. So that, it can facilitate the counselors help college student with academic procrastination problems. This development study used method or strategy developed by Borg and Gall involving 300 college student. The sample of this study were 1924 year Univercity of Kanjuruhan Malang who were selected by cluster random sampling technique, Pearson Product Moment data analysis, Cronbach Alpha, Normality test and Factor analysis. This development study produced and academic procrastination instrument consisting of 17 valid item and 5 correlated factors. So that the final result of this academic procrastination scale investment can be used for univercity counselorsnin providing follow-up service for college student.
\end{abstract}

Keywords: Inventory, Academic Procrastination; College Student

\begin{abstract}
Abstrak
Penelitian pengembangan ini bertujuan untuk menghasilkan skala prokrastinasi akademik untuk mengukur tingkat keterlambatan untuk menyelesaikan tugas-tugas yang memiliki validitas dan reliabilitas tinggi. sehingga konselor dapat membantu mahasiswa dengan masalah prokrastinasi akademik. Penelitian pengembangan ini menggunakan metode atau strategi yang dikembangkan oleh Borg dan Gall yang melibatkan 300 mahasiswa. Sampel penelitian ini adalah mahasiswa yang berumur 19-24 tahun dari Universitas Kanjuruhan Malang yang dipilih dengan teknik cluster random sampling, analisis validitas data dengan Pearson Product Moment, uji reliabilitas Cronbach Alpha, Uji Normalitas dan Analisis Faktor. Pengembangan ini menghasilkan instrumen prokrastinasi akademik yang terdiri dari 17 item yang valid dan 5 faktor yang berkorelasi. Maka hasil akhir dari investasi skala prokrastinasi akademik ini dapat digunakan oleh konselor universitas dan memberikan layanan tindak lanjut untuk mahasiswa.
\end{abstract}

Kata Kunci: Inventori, Prokrastinasi akademik, Mahasiswa

How To Cite: Faradila, U. L. F., Lasan, B. B., \& Permatasari, D. (2020). Pengembangan Inventori Prokrastinasi Akademik Bagi Mahasiswa. Biblio Couns: Jurnal Kajian Konseling dan Pendidikan, 3(1), 23-30.

\section{PENDAHULUAN}

Membangun kualitas pendidikan yang unggul di sekolah, ini berarti berkaitan dengan pengembangan prestasi akademik. Laporan dari data Programe for International Student Assesment (PISA, 2015) pada tahun 2012 menunjukan bahwasannya prestasi belajar peserta 
didik Indonesia menduduki peringkat ke 64 dari total negara yang masuk pada survei PISA (OECD, 2012). Hal ini berarti bahwa prestasi belajar peserta didik Indonesia masih tergolong rendah. Dalam proses pembelajaran, tugas diberikan oleh guru kepada siswa sebagai suatu alat atau metode dalam penyampaian materi pembelajaran. Saat proses pembelajaran juga terdapat masalah yang sering dihadapi siswa yaitu perilaku menunda-nunda tugas dalam dampak perilaku maladaptive bagi siswa dengan disengaja dilakukan secara berulang-ulang yang menyebabkan penurunan nilai akademik serta semangat belajar rendah istilah psikologi disebut disfungsional prokrastinasi akademik.

Padahal dalam konteks pembelajaran siswa diharapkan memiliki kemampuan melaksanakan tugasnya secara optimal sebagai pelajar sesuai dengan tuntutan yang dihadapi. Namun,ternyata permasalahan di lapangan, siswa sering menyepelekan tugas akademik yang diberikan oleh guru sehingga mereka tidak bisa mengumpulkannya sesuai dengan jangka waktu pengumpulan yang diberikan oleh guru, yang mana permasalahan tersebut perlu sekali penanganan dari guru bimbingan dan konseling.

Berdasarkan dari hasil observasi dan wawancara yang telah dilakukan oleh peneiti pada tanggal 1 November 2019, peneliti memperoleh informasi bahwa di SMAN 1 Jakenan terdapat anak yang mengalami disfungsional prokrastinasi akademik. Disfungsional prokrastinasi akademik merupakan masalah yang paling banyak dialami oleh siswa kelas XI MIPA 2 SMAN 1 Jakenan. Banyak gejala yang mengidentifikasi adanya siswa sering menunda tugasnya yaitu adalah 1. Menunda-nunda memulai dan mengerjakan tugas artinya siswa sengaja melakukan penundaan tersebut atau menunda-nunda untuk mengerjakan sampai tuntas jika dia sudah mulai mengerjakan sebelumnya. 2. Menunda belajar saat mengahadapi ujian artinya siswa hanya belajar disaat mendekati ujian tidak saat hari-hari biasa. 3 . Kesenjangan antara rencana dan kinerja aktual artinya memiliki kesulitan untuk melakukan sesuatu yang telah ditetapkan. 4 . Menunda kegiatan membaca catatan belajar artinya setiap mengerjakan tugas selalu mengalami kesulitan karena jarangnya minat membaca. 5 . Terbiasa mengerjakan mepet waktu artinya jika tidak mendekati dateline tugas yang diberikan guru tidak akan dikerjakan. 6 . Sengaja meninggalkan tugas yang sulit artinya tidak ada rasa tertantang untuk menyelesaikan tugas yang sulit hingga akhirnya tugas tersebut tidak dikerjakan. 7. Melakukan aktivitas lain yang lebih menyenangkan artinya melakukan aktivitas lain diluar akademik yang lebih menyenangkan misalkan lebih memilih bermain Hp daripada mengerjakan tugas. 8. Tidak memiliki tanggung jawab akademik artinya sebagai seorang siswa rasa tanggung jawab akademik seperti pengerjaan tugas tepat waktu dan teliti sangat kurang di rasakan pada siswa jaman sekarang. 9. Terlalu banyak tugas yang diberikan artinya tugas yang diberikan guru mata pelajaran lain secara bersamaan kepada siswa. 10. Takut salah terhadap tugas yang dikerjakan artinya tidak peraya diri dengan hasil yang dikerjakan sendiri akhirnya siswa menunggu temannya untuk mengerjakan, sehingga sangat diperlukan sebuah layanan konseling untuk mereduksi disfungsional prokrastinasi akademik tersebut.

Menurut Harrison (dalam kurnanto Edi; 2013) Konseling kelompok adalah konseling yang terdiri dari 4-8 konseli yang bertemu dengan 1-2 konselor. Dalam prosesnya, konseling kelompok dapat membicarakan beberapa masaah, seperti kemampuan dalam membangun relasi dan komunikasi, pengembangan harga diri, serta keterampilan-keterampilan dalam mengatasi masalah. Takut terhadap tugas yang dikerjakan artinya menunda tugas karena tidak peraya diri terhadap hasil tugas yang dikerjakan sendiri. Maka dari itu, layanan konseling kelompok dengan memakai teknik yang tepat akan dipandang efektif dan efisien dalam mereduksi prokrastinasi akademik bagi anak SMA.

Penggunaan teknik dalam melaksanakan layanan konseling kelompok sangat penting, karena sebuah teknik merupakan suatu cara yang digunakan untuk membantu keberhasilan dalam pelaksanaan konseling kelompok. Teknik yang digunakan oleh peneliti dalam melaksanakan layanan konseling kelompok yaitu teknik behavior contract.

Teknik behavior contact merupakan kesepakatan antara dua orang atau lebih untuk mengubah perilaku tertentu dan kontrak ini menegaskan harapan dan tanggung jawab yang harus dipenuhi dan konsekuensinya. Behavior Contract adalah persetujuan antara dua orang atau lebih (konselor dan klien) untuk mengubah perilkau tertentu pada klien (Latipun, 2015) . Konselor dapat memilih perilaku yang realistik dan dapat diterima oleh kedua belah pihak. 
Konselor dapat memilih perilaku yang dimunculkan sesuai dengan kesepakatan, ganjaran yang diberikan pada klien. Untuk itu, peneliti memberikan upaya dalam mereduksi disfungsional prokrastinasi akademik siswa kelas XI MIPA 2 SMAN 1 Jakenan melalui layanan konseling kelompok dengan teknik behavior contract.

\section{METODE}

Penelitian tindakan adalah penelitian Yang dilakukan profesional dengan melakukan tindakan tertentu untuk memperbaiki dan meningkatkan kualitas praktik profesional tersebut (Gall, Gall, \& Borg, 2003). Penelitian tindakan bimbingan dan konseling (BK) adalah penelitian yang dilaksanakan konselor melalui tindakan tertentu untuk memperbaiki dan meningkatkan kualitas praktik Layanan BK(Gall, Gall, \& Borg, 2003). Penelitian tindakan BK didasarkan pada masalah praktik layanan BK yang dialami konselor, dilakukan konselor dan untuk peningkatan profesionalitasnya, dan tindakan yang dilakukan berdaur untuk mencapai perbaikan layanan BK yang diharapkan (Ary, Jacobs, Razavieh, \& Sorensen, 2006). Penelitian tindakan BK dilakukan untuk memperbaiki dan meningkatkan kualitas pelayanan BK, meningkatkan profesionalitas konselor, meningkatkan akuntabilitas pelayanan BK, dan menjembatani kesenjangan praktik dan penelitian bimbingan dan konseling (Whiston, 1998). Prosedur penelitian tindakan BK merupakan suatu siklus yang terdiri atas perencanaan tindakan, pelaksanaan tindakan, observasi, dan refleksi tindakan (Kemmis \& McTaggart, 1988; Hopkins, 1993). Empat tahap penelitian tindakan tersebut membentuk suatu siklus yang diikuti oleh siklus berikutnya seperti sebuah spiral. Siklus itu berakhir saat hasil pelaksanaan tindakan sesuai dengan kriteria yang ditetapkan peneliti (Suyanto, 1998; Dasna, 2008).

Untuk menentukan karakteristik subjek, peneliti mengambil 8 orang siswa dengan menggunakan teknik purposive sampling sebagai subjek dari penelitian yang sebagian besar memiliki perilaku prokrastinasi akademik dan empat orang yang tidak prokrastinasi dari hasil observasi peneliti dan hasil wawancara dengan guru BK. Delapan orang yang ditetapkan sebagai subjek penelitian adalah AA, AQM, DA, KI, MCP, RA, TSS, YFF.

\section{HASIL PENELITIAN DAN PEMBAHASAN}

Berdasarkan hasil observasi yang telah dilakukan peneliti dan kolaborator pada tahap sebelumnya, selanjutnya peneliti melakukan refleksi untuk mengetahui peningkatan penilaian kolaborator terhadap aktvitas peneliti saat melakukan kegiatan konseling kelompok dengan teknik behavior contract, peningkatan penilaian peneliti terhadap aktivitas anggota kelompok dalam pelaksanaan konseling kelompok dengan teknik behavior contract, dan mengetahui aspek tentang disfungsional prokrastinasi akademik. Adapun rinciannya sebagai berikut:

Kondisi delapan aspek disfungsional prokrastinasi anggota kelompok pada layanan konseling kelompok dengan teknik behavior contract mengalami peningkatan dari pra siklus, siklus I, dan siklus II

Tabel 1. Hasil Peningkatan Aspek Disfungsional Prokrastinasi Akademik Siswa SMAN 1 Jakenan Layanan Konseling Kelompok Teknik Behavior Contract Pada pra siklus, Siklus I, Siklus II.

\begin{tabular}{|c|c|c|c|c|c|c|c|c|c|c|c|c|c|c|c|c|c|}
\hline \multirow{3}{*}{ No } & \multirow{3}{*}{ Nama } & \multirow{2}{*}{\multicolumn{4}{|c|}{ Prasiklus }} & \multicolumn{6}{|c|}{ Siklus I } & \multicolumn{6}{|c|}{ Siklus II } \\
\hline & & & & & & \multicolumn{2}{|c|}{1} & \multicolumn{2}{|c|}{2} & \multicolumn{2}{|c|}{3} & \multicolumn{2}{|c|}{1} & \multicolumn{2}{|c|}{2} & \multicolumn{2}{|c|}{3} \\
\hline & & S & $\mathrm{K}$ & $\mathbf{S}$ & $\mathrm{K}$ & S & $\mathrm{K}$ & S & $\mathrm{K}$ & $\mathbf{S}$ & $\mathrm{K}$ & $\mathbf{S}$ & $\mathrm{K}$ & $\mathbf{S}$ & $\mathrm{K}$ & S & $\mathrm{K}$ \\
\hline 1 & $\mathrm{AA}$ & 21 & ST & 22 & ST & 23 & $T$ & 27 & $T$ & 32 & $T$ & 33 & C & 39 & C & 48 & $\mathrm{R}$ \\
\hline 2 & AQM & 21 & ST & 21 & ST & 23 & $\mathrm{~T}$ & 28 & $\mathrm{~T}$ & 34 & $\mathrm{~T}$ & 34 & C & 36 & C & 48 & $\mathrm{R}$ \\
\hline 3 & DA & 20 & ST & 20 & ST & 25 & $\mathrm{~T}$ & 31 & C & 33 & C & 34 & C & 40 & $\mathrm{R}$ & 53 & SR \\
\hline 4 & $\mathrm{KI}$ & 22 & ST & 22 & ST & 20 & ST & 31 & $\mathrm{C}$ & 40 & C & 40 & $\mathrm{R}$ & 40 & $\mathrm{R}$ & 53 & SR \\
\hline 5 & MCP & 19 & ST & 19 & ST & 20 & ST & 29 & ST & 34 & $T$ & 36 & C & 40 & $\mathrm{R}$ & 48 & SR \\
\hline 6 & RA & 19 & ST & 19 & ST & 21 & ST & 32 & C & 36 & C & 38 & C & 40 & $\mathrm{R}$ & 44 & $\mathrm{R}$ \\
\hline 7 & TSS & 26 & $\mathrm{~T}$ & 26 & $\mathrm{~T}$ & 25 & $\mathrm{~T}$ & 34 & C & 36 & C & 38 & C & 43 & $\mathrm{R}$ & 53 & SR \\
\hline 8 & YFF & 24 & $\mathrm{~T}$ & 24 & $\mathrm{~T}$ & 30 & $\mathrm{~T}$ & 27 & $\mathrm{~T}$ & 32 & $\mathrm{~T}$ & 33 & C & 40 & $\mathrm{R}$ & 47 & C \\
\hline
\end{tabular}


Biblio Couns : Jurnal Kajian Konseling dan Pendidikan | Vol. 3 No. 1 Maret 2020

\begin{tabular}{lcccccccc}
\hline Jumlah & 172 & 173 & 187 & 239 & 105 & 286 & 318 & 394 \\
Rata-rata & 21 & 21 & 23 & 30 & 35 & 36 & 40 & 49 \\
Kategori & ST & ST & T & T & C & C & R & SR \\
\hline
\end{tabular}

Adapun hasil peningkatan aspek disfungsional prokrastinasi akademik siswa kelas XI MIPA 2 SMAN 1 Jakenan melalui layanan konseling kelompok teknik behavior contract dari pra siklus, siklus I, siklus II dapat dilihat dalam bentuk grafik berikut:

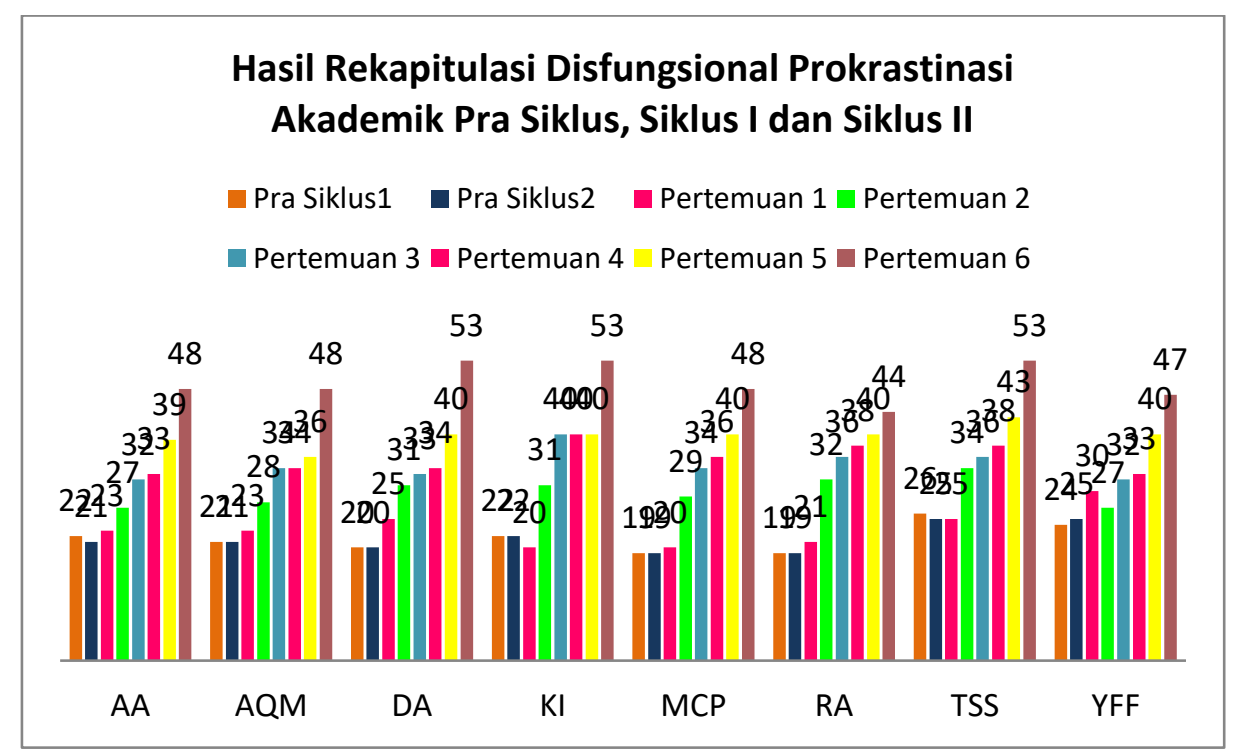

Grafik 1. Hasil Peningkatan Aspek Disfungsional Prokrastinasi Akademik Siswa Kelas XI MIPA 2 SMAN 1 Jakenan Melalui Layanan Konseling Kelompok Teknik Behavior Contrcat Pra Siklus, Siklus I, Siklus II.

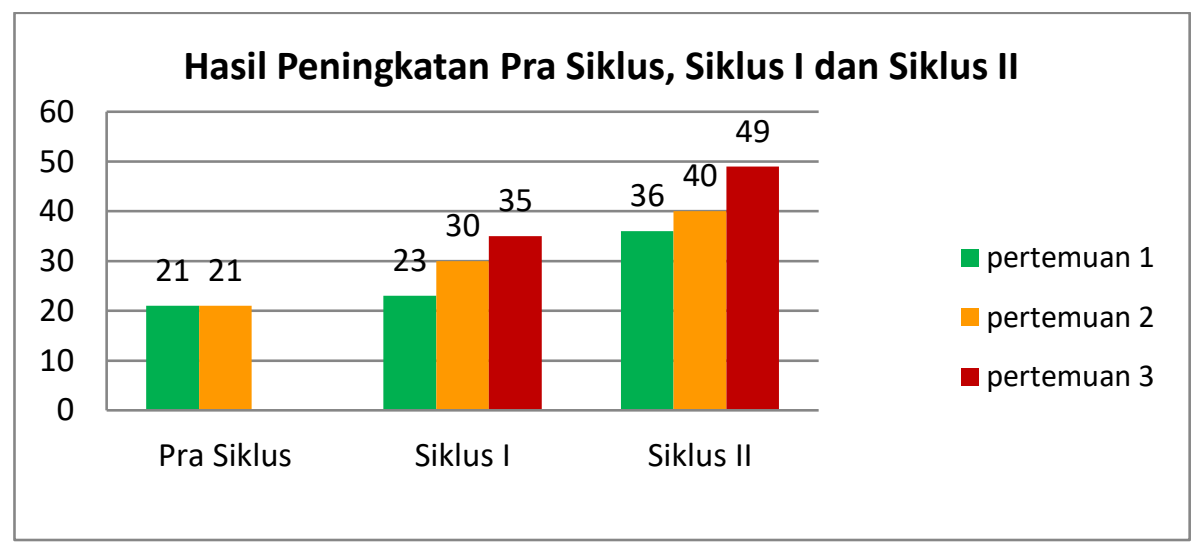

Grafik 2. Hasil Peningkatan Aspek Disfungsional Prokrastinasi Akademik Siswa Kelas XI MIPA 2 SMAN 1 Jakenan Melalui Layanan Konseling Kelompok Teknik Behavior Contrcat Pra Siklus, Siklus I, Siklus II.

Hasil dan grafik di atas, dapat diketahui bahwa aspek difungsional prokrastinasi akademik mengalami peningkatan dalam setiap pertemuannya, ini dibuktikan pada pra siklus, I dan II siswa tidak mengalami peningkatan. Pada pra siklus I dan II memiliki skor 21 dengan kategori Sangat Tinggi (ST) artinya siswa sangat tinggi kategorinya dalam melakukan aktivitas disfungsional prokrastinasi akademik, pada siklus I pertemuan pertama mengalami kenaikan sebesar 2 skor menjadi 23 skor jumlah skornya dan masuk kategori T (Tinggi), pada pertemuan kedua siklus I mengalami kenaikan 7 angka dan menjadi 30 skor masuk dalam kategori Tinggi (T), hingga pada petemuan ketiga siswa mengalami kenaikan lagi sebesar 5 angka dengan jumlah total menjadi 35 masuk dalam kategori Cukup (C). Pada pertemuan 
pertama siklus II anak mengalami peningkatan 1 skor dengan jumlah skor total 36 dengan kategori cukup (C), dan pada siklus II pertemuan kedua mengalami kenaikan jumlah skor yaitu 4 skor dengan jumlah 40 dengan kategori Rendah (R). Dan dalam pertemuan terkahir mengalami kenaikan sebesar 9 hingga mengalami jumlah skor akhir yaitu 49 dengan kategori Sangat Rendah (SR) artinya siswa sangat rendah dalam melakukan aktivitas disfungsional prokrastinasi akademik.

Hasil peningkatan kolaborator terhadap aktivitas peneliti dalam memberikan layanan konseling kelompok teknik behavior contract pada setiap pertemuannya dilihat dalam grafik berikut:

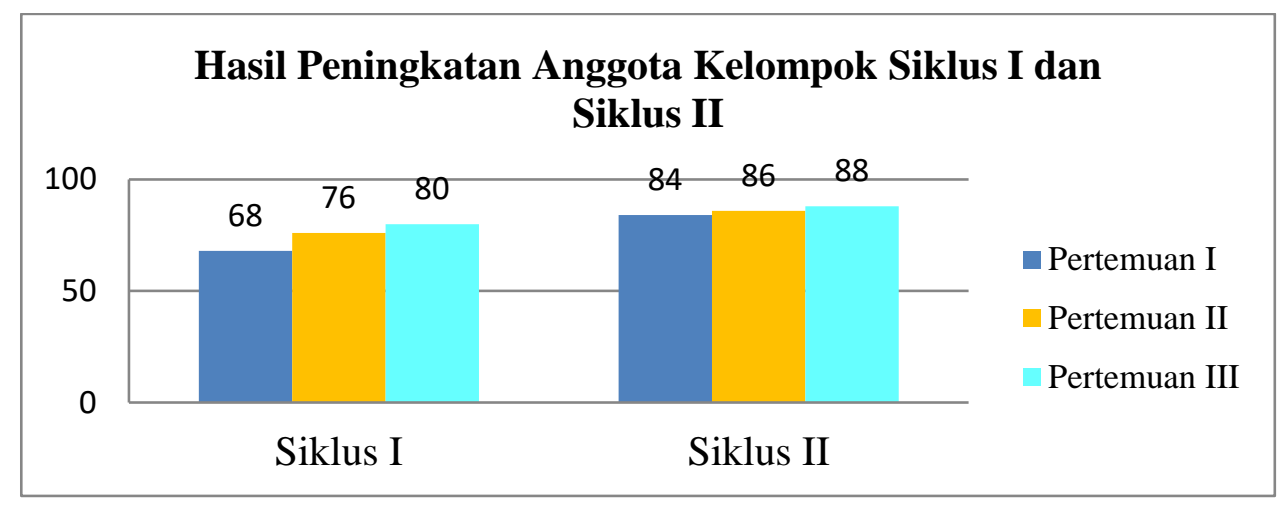

Grafik 3. Hasil Peningkatan Keterampilan Peneliti Dalam Layanan Konseling Kelompok Teknik Behavior Contract Untuk Mereduksi Disfungsional Prokrastinasi Akademik Siklus I dan II

Berdasarkan grafik maka dalam penilaian kolaborator terhadap anggota kelompok mengalami kenaikan yang siginifkan. Hal tersebut dibuktikan pada pertemuan pertama peneliti mendapatkan skor 68 dengan kategori cukup, selanjutnya peneliti mendapatkan skor 76 dengan kategori baik, dan dalam siklus I pertemuan ketiga peneliti mendapatkan skor 80 dengan kategori Baik. Selanjutnya pada siklus II pertemuan pertama peneliti mendapatkan skor 84 dengan kategori B. dan pada pertemuan kedua siklus II peneliti mendapatkan kenaikan skor sebesar 2 skor dengan kategori sangat baik. Dan pada pertemuan ketiga siklus II peneliti mendapatkan skor 88 dengan kategori sangat baik (SB).

Hasil peningkatan penilaian terhadap kegiatan anggota kelompok dalam memberikan layanan layanan konseling kelompok teknik behavior contract pada setiap pertemuannya dapat dilihat dalam bentuk grafik sebagai berikut:

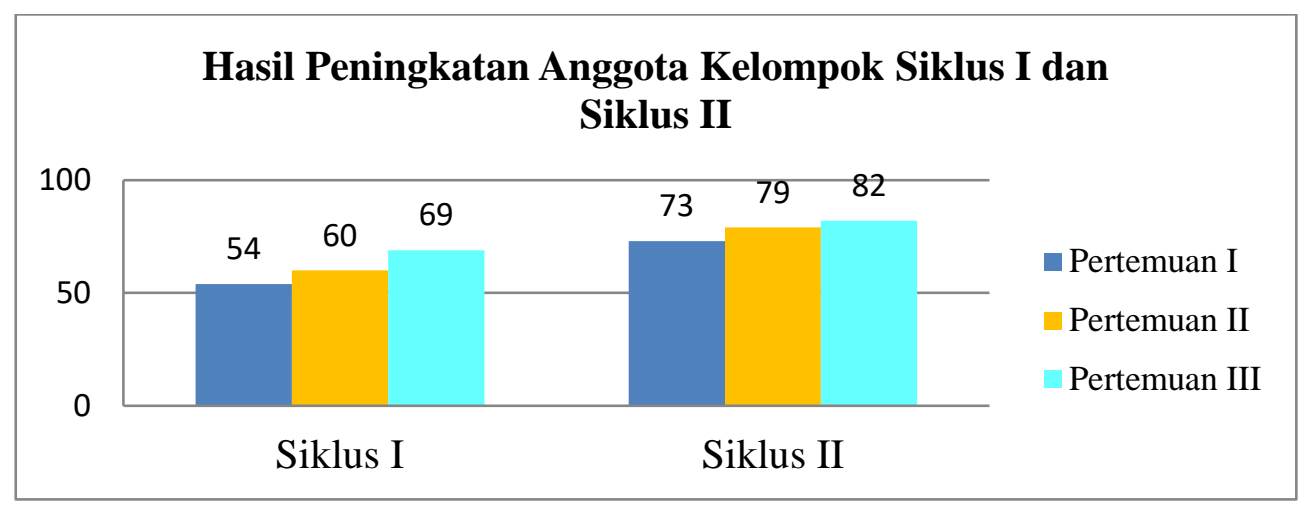

Grafik 4. Hasil Peningkatan Aktivitas Anggota Kelompok dalam Layanan Konseling Kelompok Teknik Behavior Contract Pada Siklus I dan Siklus II

Berdasarkan grafik dapat diketahui bahwa aktivitas peneliti dalam menilai anggota kelompok mengalami kenaikan hal tersebut dibuktikan pada sikus I pada pertemuan pertama anggota kelompok mendapatkan skor 54 dengan kategori cukup, selanjutnya pada pertemuan 
kedua mengalami kenaikan 6 skor senhingga jumlah skor pada pertemuan kedua yaitu 60 dengan kategori cukup, selanjutnya pada pertemuan ketiga siklus I mengalami kenaikan 9 skor sehingga jumlah skor total yaitu 69 dengan kategori baik (B). pada siklus II pertemuan pertama anggota kelompok mendapati 73 total skor dengan kategori baik (B). Pada pertemuan II siklus kedua mengalami kenaikan 6 skor sehingga jumlah skornya yaitu 79. Dan pada pertemuan II siklus Ketiga mengalami kenaikan 3 skor dengan total skor akhir yaitu 83 dengan kategori baik. Jadi dapat disimpulkan bahwa anggota kelompok mendapatkan kategori baik saat mengikuti layanan konseling kelompok teknik behavior contract pada siswa kelas XI MIPA 2 SMAN 1 jakenan.

\section{KESIMPULAN}

Berdasarkan hasil pembahasan analisis data dan refleksi, peneliti dapat mengambil kesimpulan bahwa:

1. Layanan konseling kelompok teknik behavior contract dapat mereduksi disfungsional prokrastinasi akademik pada siswa kelas XI MIPA 2 SMAN 1 Jakenan. Hal ini terbukti setelah diberi layanan konseling kelompok teknik behavior contract siklus I memperoleh skor penilaian terhadap peneliti sebesar 80 dengan kategori baik, dan pada siklus II diperoleh skor penilaian terhadap peneliti sebesar 88 dengan kategori sangat baik. Jadi, kegiatan layanan konseling kelompok dengan teknik behavior contract yang dilakukan peneliti meningkat sebanyak 8 skor dari siklus I ke siklus II.

2. Disfungsional prokrastinasi akademik pada siswa dapat direduksi setelah diberikan layanan konseling kelompok dengan teknik behavior contract. Hal ini terbukti dari hasil pra siklus diperoleh rata-rata 21 dengan kategori sangat tinggi. Sedangkan siklus I memperoleh skor rata-rata 35 dengan kategori cukup. Pada siklus II siklus kedua memperoleh skor 49 dengan kategori sangat rendah. Sehingga mengalami peningkatan 28 skor dari pra siklus ke siklus II, Artinya siswa tidak menunda-nunda dalam memulai dan menyelesaikan tugas, Tidak menunda kegiatan membaca catatan belajar, tidak mengerjakan tugas mepet waktu, tidak melakukan aktvitas lain yang lebih menyenangkan, memiliki rasa tanggung jawab akademik, tidak takut salah terhadap tugas yang dikerjakan sangat rendah.

\section{REFERENSI}

Amalia, Indah Widuri. (2012). Mengatasi Prokrastinasi Akademik Melalui Pendekatan Konseling Behavior Teknik Behavior Contractl Pada Siswa Kelas VII E SMP Negeri 13 Semarang. Tersedia online di https://lib.unnes.ac.id/12076 diakses pada 7 Desember 2019.

Arikunto, Suharisimi. 2008. Penelitian Tindakan Kelas. Jakarta: PT.Bumi Aksara.

Arikunto, Suharisimi. 2010. Prosedur Penelitian. Jakarta: Rineka Cipta.

Arikunto, Suharisimi. 2013. Prosedur Penelitian: Suatu Pendekatan Praktik. Jakarta: Rineka Cipta.

Ary, D., Jacobs, L. C., \& Razavieh, A., Sorensen, C. (2006). Introduction to research in education (7th ed.). California: Thomson Wadsworth.

Atmojo, Era Prasetyo.2009. Upaya Peningkatan Aktivitas Berpikir Kritis Melalui Model Tugas Terstruktur dan Kuis. Skripsi. Surakarta: Universitas Muhammadiyah Surakarta.

Basir, Abdul. 2018. Mengurangi Kebiasaan Menyontek Dalam Mengerjakan Ulangan Harian Melalui Layanan Konseling Kelompok Teknik Behavior Cotract Pada Siswa Kelas XI IPSMA NU MA'ARIF Kudus. Skripsi Bimbingan dan Konseling: Universitas Muria Kudus. 
Darmawan, M. Fayes. 2015. Penerapan Konseling Kelompok dengan Teknik Self Management dapat Meningkatkan Pemahaman Bahaya Judi. Skripsi tidak diterbitka. Universitas Muria Kudus: Program Studi Bimbingan dan Konseling.

Efendi, Anwar. 2009. Beberapa Catatan tentang Buku Teks Pelajaran di Sekolah. Malang: Universitas Negeri Malang.

Febriana Putri Dewi. 111114002. Tingkat Tanggung Jawab Belajar Siswa Kelas Viii Smp Negeri 13 Yogyakarkta Tahun Ajaran 2015/2016 Dan Implikasinya Terhadap Usulan Topik-Topik Bimbingan Belajar. Skripsi. Yogyakarta: Universita Sanata Dharma.

Gall, M. D., Borg, W. R., \& Gall, J. P. (2003). Educational research: An introduction (7 $7^{\text {th }}$ ed). Longman Publishing.

Ghufron, M. Nur dan Risnawitas S, Rini. 2012. Teori-teori Psikologi. Jogjakarta: Ar-Ruzz Media.

Hopkins, D. (1993). A Teacher's Guide to Classroom Research. Philadelphia. Open University Press

Husetiya, Yemina. 2010. Hubugan Asertivitas dengan Prokrastinasi Akademik Pada Mahasiswa Fakultas psikologi Diponegoro. Tersedia Online thttp://eprints.undip.ac.id/24780/1/jurnal1_mima.pdf. diakses tanggal 7 November 2019.

Jackson, M. H. 2012. Role Of Academoc Procrastination, Academic Skills On Course Outcome for College Student in Developmental education (Disertation). University of Georgia: Georgia.

Katradinata, Iven dan Tjunding, Sia. 2008. I Love You Tomorros Prokrastinasi Akademik dan Manajemen Waktu. Jurnal psikologi, 23 (2), 109-119. Tersedia online di http://repository.ubaya.ac.id/23843/1/V 023 N 002 A 002.pdf. diakses pada 7 November 2019.

Kemmis, S. and McTaggart, R. (eds) (1988) The Action Research Planner (3 ${ }^{\text {rd }}$ ed). Waurn Ponds: Deakin University Press.

Komalasari, Grantina., Eka Wahyuni, Karsih. 2011. Teori dan Teknik Konseling. Jakarta: PT. Indeks.

Kurnanto, Edi. 2013. Konseling Kelompok. Bandung: ALAFABETA.

Latipun, 2010. Teori dan Teknik Koonseling. Malang: Universitas Muhammadiyah Malang.

Latipun, 2015. Psikologi Konseling. Malang: UPT Perebitan Universitas Muhammadiyah Malang.

Lewis, Barbara. 2004.Crackter Building Untuk Remaja. Batom Centre: Kharisma Publishing Group.

Lumongga, Namora. 2016. Konseling Kelompok. Jakarta: KENCANA.

OECD. (2012). Annual Report on the OECD Guidelines for Multinational Enterprises. https://www.oecd.org/corporate/mne/2012annualreportontheguidelinesformnes.htm diakses pada 7 November 2019. 
PISA. 2015. Survei Programe for International Student Asseesment (163-172). https://www.kememdikbud.go.id/main/blog/2016/12/peringkat-dan-capaian-pisaindonesia-mengalami-peningkatan. diakses pada 7 November 2019.

Prayitno. 2012. Jenis Layanan dan Kegiatan Pendukung Konseling. Padang: FIP UM Padang.

Purnamaningsih, Esti Hayu \& Sudarjo, Siska. 2003 Kepercayaan Diri dan Kecemasan Komunikasi Interpersonal Pada Mahasiswa. Jurnal Psikologi. Yogyakarta: Universitas Gadjah Mada.

Purnamasari, Lilis Ratna. 2012. Teknik-teknik Konseling. Semarang: Universitas Negeri Semarang.

Rahadjo, Susilo \& Gudnanto. 2011. Pemahaman Individu Teknik Non Tes. Kudus: Nora Media Entrepise..

Rahadjo, Susilo \& Gudnanto. 2016. Pemahaman Individu: Teknik Nontes. Jakarta: Prenamedia Group.

Rahmat. 2013. Statistika Penelitian. Bandung: CV. Pustaka Setia.

Ratri, Sekar dan Fatma, Anne. 2013. Hubungan Antara Distres dan Dukungan Sosial dengn Prokrastinasi Akademik Pada Mahasiswa dalam Menyusun skripsi Talenta Psikologi, 2 (2), 159-180.

Rozikan, (2014) Pengaruh Layanan Konseling Kelompok dengan Pendekatan Behavioral Terhadap Prokrastinasi Akademik Siswa Kelas XI SMK Perintis Ungaran tahun Ajaran 2014/2015. Tersedia online di https://journal.unnes.ac.id diakses pada 7 Desember 2019.

Sanjaya, Wina. 2012. Penelitian Tindakan Kelas. Jakarta: Kencana.

Seila Dina, Ariba. 2019. Mereduksi Penggunaan HandPhone Saat Pembelajaran Melalui Bimbingan Kelompok Teknik Behavior Contract. Universitas Muria Kudus: Program Studi Bimbingan Dan Konseling.

Siswanto, Dwi. 1997. Kesadaran dan Tanggung Jawab Pribadi dalam Humanisme Jean-Paul sarte. Jurnal Filsafat, VII 30-31.

Sugiyono. 2015. Metode Penelitian (Pendeketan Kuantitatif, Kualitatif, dan R\&D. Bandung: Alfabeta.

Sukiman. 2011. Penelitian Tindakan Kelas untuk Guru Pembimbing (Bimbingan dan Konseling) Dilengkapi Contoh Proposal dan Laporan PTK-BK. Yogyakarta: Paramitra Publishing.

Tadjri, Imam. 2014. Penelitian Tindakan Bimbingan dan Konseling. Semarang: CV. Swada Manunggal.

Undang-undang Republik Indonesia. 2003. Permendikbud nomor 23: Sistem Pendidikan Nasiona. Hukum.unsrat.ac.id/uu/uu_23_2003.htm. tersedia online, diakses pada 7 November 2019.

Wahyuni, Septi. 2016. Peningkatan kedisiplinan Siswa Melalui Teknik Kontra Perilaku (Behavior Contract)) di TK ABA Pakis. Jurnal Pendidik Anak Usia Dini, 3 (5), 8. 